IRA-International Journal of Applied Sciences ISSN 2455-4499; Vol.08, Issue 01 (July 2017)

Pg. no. $18-30$

Institute of Research Advances

https://research-advances.org/index.php/IRAJAS

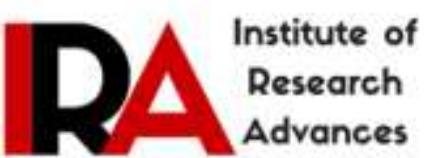

\title{
Adsorption Study of the Removal of Copper (II) Ions using Activated Carbon Based Canarium Schweinfurthii Shells Impregnated with $\mathrm{ZnCl}_{2}$
}

\author{
Kammegne Adelaide Maguie ${ }^{1,}$, Ndi Julius Nsami ${ }^{2}$, Kouotou Daouda ${ }^{3}$, Che Nangah Randy ${ }^{4}$, \\ Ketcha Joseph Mbadcam ${ }^{5}$ \\ $\mathbf{1 , 2 , 3 , 4 , 5}$ Applied Physical and Analytical Chemistry Laboratory, Department of Inorganic Chemistry, \\ Faculty of Science, University of Yaoundé I, P.O. Box 812, Yaoundé, Cameroon.
}

Type of Review: Peer Reviewed.

DOI: http://dx.doi.org/10.21013/jas.v8.n1.p2

\section{How to cite this paper:}

Maguie, K., Nsami, N., Daouda, K., Randy, C., Mbadcam, K.(2017). Adsorption Study of the Removal of Copper (II) Ions using Activated Carbon Based Canarium Schweinfurthii Shells Impregnated with ZnCl2. IRA International Journal of Applied Sciences (ISSN 2455-4499), 8(1), 18-30. doi: http://dx.doi.org/10.21013/jas.v8.n1.p2

(C) Institute of Research Advances.

\section{(cc) BY-NO}

This work is licensed under a Creative Commons Attribution-Non Commercial 4.0 International License subject to proper citation to the publication source of the work.

Disclaimer: The scholarly papers as reviewed and published by the Institute of Research Advances (IRA) are the views and opinions of their respective authors and are not the views or opinions of the IRA. The IRA disclaims of any harm or loss caused due to the published content to any party.

Institute of Research Advances is an institutional publisher member of Publishers Inter Linking Association Inc. (PILA-CrossRef), USA. The institute is an institutional signatory to the Budapest Open Access Initiative, Hungary advocating the open access of scientific and scholarly knowledge. The Institute is a registered content provider under Open Access Initiative Protocol for Metadata Harvesting (OAI-PMH).

The journal is indexed \& included in CAS Source Index of Chemical Abstracts Service of American Chemical Society (USA), WorldCat Discovery Service (USA), CrossRef Metadata Search (USA), WorldCat (USA), OCLC (USA), Open J-Gate (India), EZB (Germany) Scilit (Switzerland), Airiti (China), Bielefeld Academic Search Engine (BASE) of Bielefeld University, Germany, PKP Index of Simon Fraser University, Canada. 


\begin{abstract}
The adsorption of $\mathrm{Cu}^{2+}$ ions on activated carbon based canarium schweinfurthii impregnated with $\mathrm{ZnCl}_{2}$ was studied. The shells of canarium schweinfurthii were impregnated with $\mathrm{ZnCl}_{2}$ at varying $\mathrm{ZnCl}_{2}$ concentrations, temperature, residence time while keeping the heating rate fixed at $10{ }^{\circ} \mathrm{C} / \mathrm{min}$ and the ratio of impregnation of $1: 1$. The activated carbon with the highest surface area in term of iodine number of $860,817 \mathrm{mg} / \mathrm{g}$, the highest methylene blue of $741,6 \mathrm{mg} / \mathrm{g}$ and 74,66\% of yield of carbon was obtained at $650{ }^{\circ} \mathrm{C}, 60 \% \mathrm{ZnCl} \mathrm{C}_{2}$ and 30 min. From the batch adsorption studies, the equilibrium time was found to be 40 min. Analysis of equilibrium isotherm models revealed a good correlation of the experimental data with the Tempkin $\left(R^{2}=0.909\right)$ model. This confirms a high affinity of the activated carbon for $\mathrm{Cu}^{2+}$ ions on the heterogeneous surface. The value of energy obtained from the Tempkin model was 60,606 J/mol and the presence of pics between $487 \mathrm{~cm}^{-1}$ to $871 \mathrm{~cm}^{-1}$ indicating that physisorption and chemisorption were taking place during this sorption. The pseudo-second order kinetics $\left(R^{2}=0.999\right)$ governs the adsorption of $\mathrm{Cu}^{2+}$ ions on this activated carbon.
\end{abstract}

Keywords: adsorption, physisorption, chemisorptions, activated carbon, isotherm, kinetics.

\title{
Introduction
}

Nowadays, water pollution by dyes, pesticides and heavy metals in particular is an environmental calamity. Indeed heavy metals like copper, zinc, cadmium cobalt nickel are particularly dangerous because they are nonbiodegradable, toxic even at low doses, and they can-accumulate in the human body [1]. Copper is an .essential trace element for human metabolism, however, it is toxic at concentrations above $2 \mathrm{mg} / \mathrm{L}$ [2]. Ingestion of large doses irritate the mucous membranes, damage the hair and can cause necrotic changes in the liver and kidneys [3].Copper is present in wastewaters coming from energy industries (such as PILCAM in Cameroon), the production of certain pesticides and in the manufacture of contraceptives in medicine. [2]

Faced to this problem it is urgent to reduce their quantity, in order to minimize their impact on the environment. Several methods such as reverse osmosis, electrolysis, ion exchange, membrane separation, sedimentation, coagulation, flocculation and adsorption have emerged for the removal of pollutants from waters. Adsorption is most commonly used because its simplicity, economical and easier to operate [3].Its exploitation requires the use of adsorbent on which pollutants are capable to be attached on their surface. Many adsorbents such as are zeolites, silica gel, clay and activated carbon are being used. Activated carbon is the most effective adsorbent used in industrial water treatment because of it large surface area which makes it a powerful adsorbent [4, 5]. It is usually produced in powder form or as grains, depending on the type of pollutant to be adsorbed.

In this work, activated carbon was prepared from the canarium schweinfurthii shells, a readily available equatorial and tropical fruit. This carbon will be tested for its ability to remove $\mathrm{Cu}^{2+}$ ions from aqueous solution. Equilibrium and kinetics adsorption studies were carried out to certify, without risk of error, that this carbon can be used for such purposes in the future. Kana J. R and al (2014) have done the Growth performance and carcass characteristics of broiler chickens fed diets supplemented with graded levels of charcoal from maize cob or seed of Canarium schweinfurthii England not give any information about the characteristics about this biochar. A.S. Olawale and all have done the Thermal Activation of Canarium Schweinfhurthi Nutshell and obtained the specific surface of $411.99 \mathrm{~m}^{2} / \mathrm{g}$. Bassey and al. have done Adsorption Isotherm, Kinetics and Thermodynamics Study of $\mathrm{Cr}(\mathrm{VI})$ ions onto Modified Activated Carbon from endocarp of Canarium schweinfurthii and not give any information about the characteristic. Additionally, as far as our knowledge there are no much works dealing with preparation of activated by chemical activation of canarium schweinfurthii.

\section{Materials and method}

\section{Preparation of adsorbent and adsorbate}

From the results of TGA analysis on the biomass, we varied the carbonization temperature from $500-800{ }^{\circ} \mathrm{C}$. The residence time was varied from 45 to $120 \mathrm{~min}$, the concentration of $\mathrm{ZnCl}_{2}$ (45 to 60\%), and at constant impregnation ratio of 0.6 . A volume of $10 \mathrm{~mL}$ of $\mathrm{ZnCl}_{2}$ at desired concentration was mixed uniformly with $10 \mathrm{~g}$ of canariun schweinfurthii., shell and placed in an oven (brand) for 24 hours. After carbonization, the impregnated char was washed with distilled water until disappearance of precipitates of silver chlorine. The activated carbon obtained was dried, crushed and sieved using an $80 \mu \mathrm{m}$ diameter sieve.

\section{Characterization}

Thermogravimetric Analysis (TGA) was carried out on the biomass using a LINSEIS STA PT-1000 instrument. The measure of the specific surface area of the activated carbon was obtained through iodine number and 
methylene blue adsorption [6,7].The $\mathrm{pH}$ of zero point charge was determined by plotting the initial $\mathrm{pH}$ as a function of the final $\mathrm{pH}$ of a mixture of $\mathrm{NaCl}$ and adsorbent. [5, 8,9]. Fourier Transform IR was carried using BRUKER Alpha-P using ethanol as solvent, and I/PSEM2, EDX microscope.

\section{Adsorption studies}

Batch adsorption studies were carried out to study the adsorption of $\mathrm{Cu}^{2+}$ ions on the activated carbon. The $\mathrm{pH}$ of the $\mathrm{Cu}^{2+}$ ions solution was adjusted using $0.1 \mathrm{M} \mathrm{HCL}$ and $0.1 \mathrm{M} \mathrm{NaOH}$.

A certain mass of the adsorbent is added to $20 \mathrm{ml}$ of copper solution and stirred for a predetermined time at room temperature. After equilibrium, the solution was filtered using a Whatman No 1 filter paper and the residual concentration of copper determined using a Techmel \& Techmel. USA S 23A UV spectrophotometer. The amount adsorbed $\left(\mathrm{Q}_{\mathrm{e}}\right)$ was calculated using Equation 1,

$Q_{e}=\frac{\left(C_{0}-C_{e}\right)}{m} \times V$

where, $\mathrm{C}_{\mathrm{o}}$ and $\mathrm{C}_{\mathrm{e}}$ is the initial and equilibrium concentration of adsorbent $(\mathrm{mg} / \mathrm{l}), \mathrm{V}$ is the volume of the solution (L), and $\mathrm{m}$ the mass of adsorbent.

The influences of the parameters such as $\mathrm{pH}$ of the solution, the concentration of the adsorbate, the mass of adsorbent and equilibrium time were studied. Kinetic studies were conducted by varying the time between 10 120 mins with $0.025 \mathrm{~g}$ of adsorbent and $20 \mathrm{~mL}$ of adsorbate.

\section{Results and Discussion}

\section{Characterization of adsorbent \\ SEM-EDX}

Figure 1shows the surface morphology of the ACZ as determined by SEM analysis, with the presence of pores on the surface of the ACZ compared to the biomass. An accumulation of zinc ions on the activated carbon surface resulting from the complexation of zinc with $-\mathrm{C}=\mathrm{O}$ surface groups is observed. The presence of $\mathrm{Zn}^{2+}$ and $\mathrm{Cl}^{-}$ions on the activated carbon surface will be further confirmed by FTIR results, confirming the modification of the activated carbon by $\mathrm{ZnCl}_{2}$ [4]

\section{Figure 1: SEM of the biomass (a) and the $\operatorname{ACZ}(b)$}

\section{The Iodine Number}

Iodine number determination gave an idea on the specific surface area. For the ACZ, the values of $860,817 \mathrm{mg} / \mathrm{g}$ and $741,6 \mathrm{mg} / \mathrm{g}$. are the iodine and methylene blue numbers respectively.

\section{FTIR}

FTIR spectra of the biomass (a), $\mathrm{ZnCl}_{2}$ activatedcarbon (b) and $\mathrm{ZnCl}_{2}$ activated carbon after adsorption of $\mathrm{Cu}^{2+}$ (c) are in the Figure (2).The band at $3352.685 \mathrm{~cm}^{-1}$ of the biomass is characteristic of -OH vibration of water. This band is shifted to $2996.823 \mathrm{~cm}^{-1}$ for the activated carbon due to the effect carbonization. The weak band at $744.451 \mathrm{~cm}^{-1}$ ischaracteristic of a halogen containing compounds and can be attributed to the $\mathrm{C}-\mathrm{X}$ stretch of chlorine heterocyclic molecules. The bands from 1000 to $1300 \mathrm{~cm}^{-1}$ are attributed to the C-O-C-aromatic vibration. The bands between $2912-2998 \mathrm{~cm}^{-1}$ represent $-\mathrm{CH}_{2}$ asymmetric stretching vibration and confirm the presence of methylene groups. The band at $1624 \mathrm{~cm}^{-1}$ confirms the presence of ethers. The figures $2 \mathrm{a}, 2 \mathrm{~b}$ and $2 \mathrm{c}$ are the FTIR of biomass, activated carbon $\mathrm{AC}-\mathrm{ZnCl}_{2}$ before and after adsorption respectively.

\section{Batch adsorption studies}

\section{Effect of initial $\mathrm{pH} \mathrm{Cu}^{2+}$ adsorption}

The influence of $\mathrm{pH}$ on the adsorption of $\mathrm{Cu}^{2+}$ ions using the $\mathrm{ZnCl}_{2}$ activated carbon was studied by varying the $\mathrm{pH}$ from 2.23 to 5. The amount adsorbed increases with $\mathrm{pH}$ up to a maximum of $36.4 \mathrm{mg} / \mathrm{g}$ at a pH of 4 (Figure 3 ). The $\mathrm{pH}$ of zero-point charge of $\mathrm{ACZ}$ was found to be 7,1 , hence, the surface is positively charged at $\mathrm{pH}$ lower than 7 , and negatively charged at $\mathrm{pH}$ greater than 7,1 . The $\mathrm{Cu}^{2+}$ ions which are positively charged can easily establish the bonds with the $-\mathbf{C}=\mathbf{O}$, and-COO surface groups on the ACZ, thus the high adsorption of $\mathrm{Cu}^{2+}$ ions at $\mathrm{pH}$ less than $5[10,11,12,13]$.. This trend can also be explained by the contribution of $\mathrm{Cl}^{-}$ attachment on the adsorbent which changes the nature of the surface thus promoting the affinity with the $\mathrm{Cu}^{2+}$ ions $[14,15,16]$. Others studies have reported that the maximum adsorption of $\mathrm{Cu}^{2+}$ ions occurred at low $\mathrm{pH}(\mathrm{Q}=88.8 \mathrm{mg} / \mathrm{g}$ for $\mathrm{pH}=4)[12,13,17,18]$, and that $\mathrm{Cu}^{2+}$ ions precipitates at $\mathrm{pH}$ greater than 4 . The major mechanisms responsible for metal uptake in this range may be attributed to the ion exchange and electronic 
attraction. Through adsorption may give best results at $\mathrm{pH}$ values greater than 7,1 because of the affinity and absence of repulsion effect. To avoid precipitation, the $\mathrm{pH}$ equal to 5 was used

\section{Effect of contact time}

The contact time was varied from 10 to $120 \mathrm{~min}$, at constant concentration of $600 \mathrm{mg} / \mathrm{L}$. This variation is represented in Figure 4 below. The equilibrium time was reached after $30 \mathrm{~min}$ with $52.4 \mathrm{mg} / \mathrm{g} \mathrm{of} \mathrm{Cu}^{2+}$ ions adsorbed.

\section{Effect of the adsorbent dose}

The mass of adsorbent was varied between 0.025 to 0.1 gat a constant initial concentration of $600 \mathrm{mg} / \mathrm{L}$ at the equilibrium time of $30 \mathrm{~min}$ and $\mathrm{pH}$ of 4 . The quantity of $\mathrm{Cu}^{2+}$ ions adsorbed as a function of the adsorbent dose is given on Figure 5 below. The quantity adsorbed seems to decrease with an increase in the adsorbent dose. This may be due to the aggregation on the adsorption sites as the amount of adsorbent increase [19,20,21,22]. The maximum quantity of $\mathrm{Cu}^{2+}$ ions adsorbed at these conditions was $88,4 \mathrm{mg} \cdot \mathrm{g}^{-1}$ with $0.025 \mathrm{~g}$ of adsorbent.

Effect of the initial concentration $\mathrm{Cu}^{2+}$ ions

The quantity of $\mathrm{Cu}^{2+}$ ions adsorbed increased with increasing $\mathrm{Cu}^{2+}$ ion concentration (Figure 6) and the maximum adsorption capacity obtained was $108,4 \mathrm{mg} / \mathrm{g}$ recorded at $\mathrm{Co}=1800 \mathrm{mg} / \mathrm{L}$.

\section{Adsorption kinetics}

\section{Pseudo-first order model}

The integrated form of the pseudo-first order model (equation 2) with boundary conditions ( $\mathrm{t}=0$ to $\mathrm{t}=\mathrm{t}$ and $\mathrm{Qt}=0$ to $\mathrm{Qt}=\mathrm{Qt}$ ) was applied.

$$
\operatorname{Ln}\left(\mathrm{Q}_{\mathrm{e}}-\mathrm{Q}_{\mathrm{t}}\right)=\ln \mathrm{Q}_{\mathrm{e}}-\mathrm{K}_{1} \mathrm{t}
$$

where, Qe and Qt are the adsorption capacity at the equilibrium and time $\mathrm{t}$ respectively ( $\mathrm{mg} / \mathrm{g}$ ), $\mathrm{K}$ is the rate constant of pseudo-first order equation $\left(\mathrm{min}^{-1}\right)$. This equation is verified if the plots of $\ln (\mathrm{Qe}-\mathrm{Qt})$ as function of time give a straight line. $\mathrm{K}_{1}$ is deduced from slope and $\mathrm{Qt}$ from the vertical intercept. The Figure 7 below describes the pseudo-first order model.

\section{Pseudo-second order model}

The linear form of the pseudo second order adsorption kinetic rate equation is expressed as:

$$
\mathrm{t} / \mathrm{Q}_{\mathrm{t}}=1 / \mathrm{K}_{2} \mathrm{Qe}^{2}+\mathrm{t} / \mathrm{Q}_{\mathrm{e}}
$$

Where $\mathrm{K}_{2}$ is the rate constant of the pseudo second order adsorption. The Figure 8 below describes the pseudosecond order model.

The correlation coefficient $\left(\mathrm{R}^{2}\right)$ of the pseudo second order model is closest to unity, implying a significant agreement of the experimental data to this model. Hence, the physisorption. At the same time, the $R^{2}$ value $(R=$ 0,934) of the pseudo-first-order cannot be neglected. It is sufficiently close to unity indicating that chemisorption and physisorption takes place concomitantly [21]. This conclusion is consistent to the results of isotherms and IR obtained above.

\section{Adsorption isotherms studies}

The linearized form of the Langmuir, Freundlich and Tempkin isotherm models are given by the equation 4 , equation 5 and equation 6 respectively:

$$
\begin{aligned}
& \mathrm{C}_{\mathrm{e}} / \mathrm{Q}_{\mathrm{e}}=1 / \mathrm{Q}_{\max } \mathrm{K}+\mathrm{Ce} / \mathrm{Q}_{\max } \\
& \ln \mathrm{Q}_{\mathrm{e}}=\ln \mathrm{K}_{\mathrm{F}}+\ln \mathrm{Ce} \\
& \mathrm{Q}_{\mathrm{e}}=\mathrm{B} \ln \mathrm{K}_{\mathrm{T}}+\mathrm{B} \ln \mathrm{C}_{\mathrm{e}}
\end{aligned}
$$

where Qe is the quantity adsorbed at equilibrium $(\mathrm{mg} / \mathrm{g}), \mathrm{Q}_{\max }$ is the maximum adsorption capacity corresponding to complete monolayer coverage, $\mathrm{K}_{\mathrm{L}}$ is the Langmuir constant related to the energy of adsorption $(\mathrm{L} / \mathrm{mg}) . \mathrm{K}_{\mathrm{F}}$ is the Freundlich constant, $1 / \mathrm{n}$ the heterogeneity factor which is related to the capacity of the adsorption. $\mathrm{C}_{\mathrm{e}}$ the concentration at the equilibrium of the adsorbat $(\mathrm{mg} / \mathrm{g}) . \mathrm{B}=\mathrm{RT} / \mathrm{bT}$ is the adsorption energy constant $(\mathrm{J} / \mathrm{mol})$

The isotherm studies were carried out by varying the $\mathrm{Cu}^{2+}$ ions concentration from 600 to $1800 \mathrm{mg} / \mathrm{Lat}$ room temperature. The Figure 8 (a),(b) and (c)describes the Langmuir, Freundlich and Tempkin isotherms. 
The isotherm characteristic helps to determine whether the adsorption is favorable or not. The low value of $\mathrm{K}_{\mathrm{L}}$ and $\mathrm{R}^{2}$ described that the Langmuir model is not suitable to explain the adsorption of $\mathrm{Cu}^{2+}$ onto ACZ. The Freundlich constants $n$ ranging 1 and 10 determine that the adsorption is favorable or not [22]. On the Table 2 above, $n=1,75$ which is greater than 1 . And it implies that the activated carbon surface is heterogeneous. The value of $\mathrm{R}^{2}$ low than 0,9 restricts the use of this model to well describe the adsorption of the $\mathrm{Cu}^{2+}$ ions adsorption onto this sample. The value of Tempkin isotherm constant (B) constant is positive and $R^{2}=0,999$ implies that the interactions between adsorbent-adsorbate is gravitational. The presence of $-\mathrm{CO}$ and $-\mathrm{COO}-$ on the ACZ surface explains well these interactions. [23,24]

\section{Conclusion}

Activated carbon impregnated with $\mathrm{ZnCl}_{2}$ has been used as adsorbent in this work. The adsorption of $\mathrm{Cu}^{2+}$ onto ACZ depends on of the $\mathrm{pH}$ and the initial concentration. The pseudo- second order and first order models explained that the adsorption mechanism is both chemisorption and physisorption and takes place concomitantly. Tempkin isotherm described well the adsorption of $\mathrm{Cu}^{2+}$ ions; hence, we can conclude that the $\mathrm{ACZ}$ is good for the adsorption of $\mathrm{Cu}^{2}+$. The major mechanisms responsible for the $\mathrm{Cu}^{2+}$ ions uptake in this range may be ion exchange and electronic attraction.

\section{Acknowledgement}

The authors thank the Panafrican Materials Institute of Nigeria for the SEM analysis provided.

\section{References}

[1] Mondal, N.K., Bhaaumik, R., Baur, T., Das, B.A., Roy, P., and Datta, J.K., ' 'Studies on defluoridation of water by tea ash: an unconventional biosorbent', Chemical Science Transactions, vol. 1, no. 2, 239256, May. 2012.

[2] Horsfall M.J., Abia A. A., Spiff A. I., "Kinetic studies on the adsorption of Cd(II), Cu(II) and Zn(II) ions from aqueous solutions by cassava tuber bark waste, "Bioressource and Technology, vol. 97,no.2 pp. 283-291.January 2006.

[3] Anagho Gabche S., Ketcha Mbadcam J., Kammegne A. M., Ndi Nsami J., Nche Ndifor-Angwafor G., and Tchuifon Tchuifon D.R., "Equilibrium, Kinetic and Thermodynamic studies of Phosphoric acid adsorption onto Activated Carbon”, Dee Chemica Sinica.vol. 4. no. 3, 2013, pp. 58-68.

[4] Kana J. R., Teguia A. Tchoumboue. J.," Effect of charcoal from Canarium schweinfurthii kernel and from maize cob on the production performances of broiler chickens fed a diet containing peanut cake as main plant protein source."International Network for family poultry development.vol. 19, no. 1, pp. 1- 52. Jun 2010.

[5] Abega V. A., Ndi Nsami J., Manga Ngomo H, Kouotou D., Yanou Nkwaju R., Numbonui Ghogomu J, Mbadcam Ketcha J. «The Performance of Activated Carbon Based Cola Nuts Shells for the Removal of $\mathrm{Co}(\mathrm{II})$ and $\mathrm{Ni}(\mathrm{II})$ Ions from Aqueous Solution" International Journal of Innovative Science, Engineering \& Technology, vol. 2 no 7, pp. 676-689, July 2015.

[6] Kouotou D., Ngomo H. Manga, Baçaoui A., Yaacoubi A., Ketcha Mbadcam J., '’Physicochemical activation of oil palm shells using response surface methodology: optimization of activated carbons preparation'. International Journal of Current Research. vol 5, no. 2013 pp 431-438, August 2012.

[7] Nkwaju Yanou R. N., Ndi Nsami J., Belibi Belibi P., Kouotou D., Abega V.A., Tcheompi M.B., Mbadcam, Ketcha J., "Adsorption of manganese (II) ions from aqueous solutions onto Granular Activated Carbon (GAC) and Modified Activated Carbon (MAC)" International Journal of Innovative Science, Engineering \& Technology vol.2,no.8 pp. 606-614, August 2015

[8] Tagne G. M., Ndi Nsami J.and Ketcha Mbadcam J., "Adsorption of Copper (II) Ions from Aqueous Solution onto Synthetic Goethite and Two Naturally Available Red Soils from Yaoundé-Cameroun", British Biotechnology Journal, vol. 2, no3pp. 221-235, July 2013.

[9] U.Bassey M. A. T. Suleiman S. S. Ochigbo, M. M. Ndamitso E. D. Daniel S. E. Otoloand A. Chukwudi. "Adsorption Isotherm, Kinetics and Thermodynamics Study of Cr (VI) ions onto Modified Activated Carbon from endocarp of Canarium schweinfurthii "International Research Journal of Pure \&Applied Chemistry, vol. 6, no. 1, December 2014.

[10] A.S. Olawale and O.A Ajayi "Thermal Activation of Canarium Schweinfhurthi Nutshell” Australian Journal of Basic and Applied Sciences, vol. 3 no.4, pp. 3801-3807, 2009,

[11] Dada A., Olalekan A., Olatunya M. and Dada O., "Langmuir, Freundlich, Tempkin and DubininRadushkevich Isotherms Studies of Equilibrium Sorption of $\mathrm{Zn}^{2+}$ onto Phosphoric Acid Modified Rice Husk", Journal of Applied Chemistry, vol. 3, no.1pp. 38-45, December 2012. 
[12] Ho, Y.S. 'Removal of metal ions from sodium arsenate solutions using tree fern', Process Safety and Environmental Protection, vol. 81, no. 5, pp. 352-356, Sep. 2003.

[13] Jiang, M.J., Xiao-ying, L., Xiao-Qiao, C., and Zu-liang, ' Adsorption of Pb(II), Cd(II), Ni(II) and $\mathrm{Cu}(\mathrm{II})$ onto natural kaolinite clay', Desalination, vol. 252, no. 1-3, pp. 33-39, Mar. 2010.

[14] An, H.K., Park, B.Y., and Kim, D.S., 'Crab shell for the removal of heavy metals from aqueous solution”, Water Research, vol. 35, no. 15, pp. 3551-3556, Oct. 2001

[15] Fumba G., Essomba J. S., Tagne G. M., Ndi Nsami J., Belibi Belibi P. D. and Ketcha Mbadcam J., "Equilibrium and Kinetic adsorption Studies of Methyl Orange from Aqueous Solutions Using Kaolinite, Metakaoloinite and Activated Geopolymer as Low Cost Adsorbents", Journal of Academia and Industrial Research, vol. 3,no4 pp. 156-163, September 2014.

[16] Dalida, M.L.P., Mariano, A.F.V., Futalan, C.M., Kan, C.C., Tsai, W.C. and Wan, M.W. '’Adsorptive removal of $\mathrm{Cu}(\mathrm{II})$ from aqueous solutions using non-cross linked and cross linked chitosan-coated bentonite beads", Desalination.vol. 275, no. 1-3, pp. 154-159, Jul. 2011.

[17] Ndi Nsami J., Ketcha Mbadcam J., "The adsorption efficiency chemically prepared activated carbon from coma nut shells by $\mathrm{ZnCl} 2$ on methylene Blue". Journal of Chemistry. vol. 2013, pages 1-7, May 2013.

[18] Kanthimathi G., Kotteswaran P., Thillai Arasu P.,.Govidaraj P., Kottaisany M.. «A comparative study of the adsorption efficiency of the newly synthetic nano iron oxide and commercial activated charcoal towards the removal the nickel II) ions". E.Journal of Chemistry. vol 9,no4 pp $2384-2393$. February 2012.

[19] Singh C.K, Sahn J.N, Mahalik K.K., Mohanty C.R., Ray B. Mohan, Meikap B.C. "Study on the removal of $\mathrm{Pb}(\mathrm{II})$ from water by activated carbon developed from tamarin wood activated with sulfuric acid". Journal of Hazardous Material. vol 153. No1-2 pp 221 - 228, May 2008.

[20] Meena A.K, Mishra G.K., Rai P.K, Rajagopal C., Nagar P.N."Removal of heavy metal ions from aqueous solution using carbon aerogel as an adsorbent". Journal of Hazardous Material. vol. 27. no.12 pp $1-11$, Jun 2005.

[21] Idris S., Iyaba Y. A., Dauda B.E.N., Ndaminso M.N., Umar M.T. "Kinetic study of utilizing groundnut shells as an adsorbent in removing chromium and Nickel from Dye Effluent." American Chemical Science Journal. vol 2, no7 pp 12 - 24, 2012.

[22] Hamadi A.E., Arsalane S., Halim M., "Kinetics and isotherm studies of copper removal by brunshite calcium phosphate: linear and nonlinear regression comparison". E.Journal of Chemistry. vol 9.no.3 pp 1532 - 1542, January 2012.

[23] Samarghandi M., Hadi M., Moayedi S., and Barjasteh A., "Two-Parameter Isotherms of Methyl Orange Sorption by Pinecone Derived Activated Carbon", Iranian Journal of Environmental Health and Scientific Engineering, vol. 6, no.4 pp. 285-29, March 2010.

[24] Dina Joh D. D., Abdoul Rahman N., Ndi Nsami J. and Ketcha Mbadcam J., "Adsorption of acetic acid onto activated carbons obtained From Maize Cobs by Chemical Activation with Zinc Chloride (ZnCl2)", Research Journal of Chemical Sciences, vol. 2no.9, pp. 42-49, Jun 2012. 


\section{TABLES \& FIGURES Section}

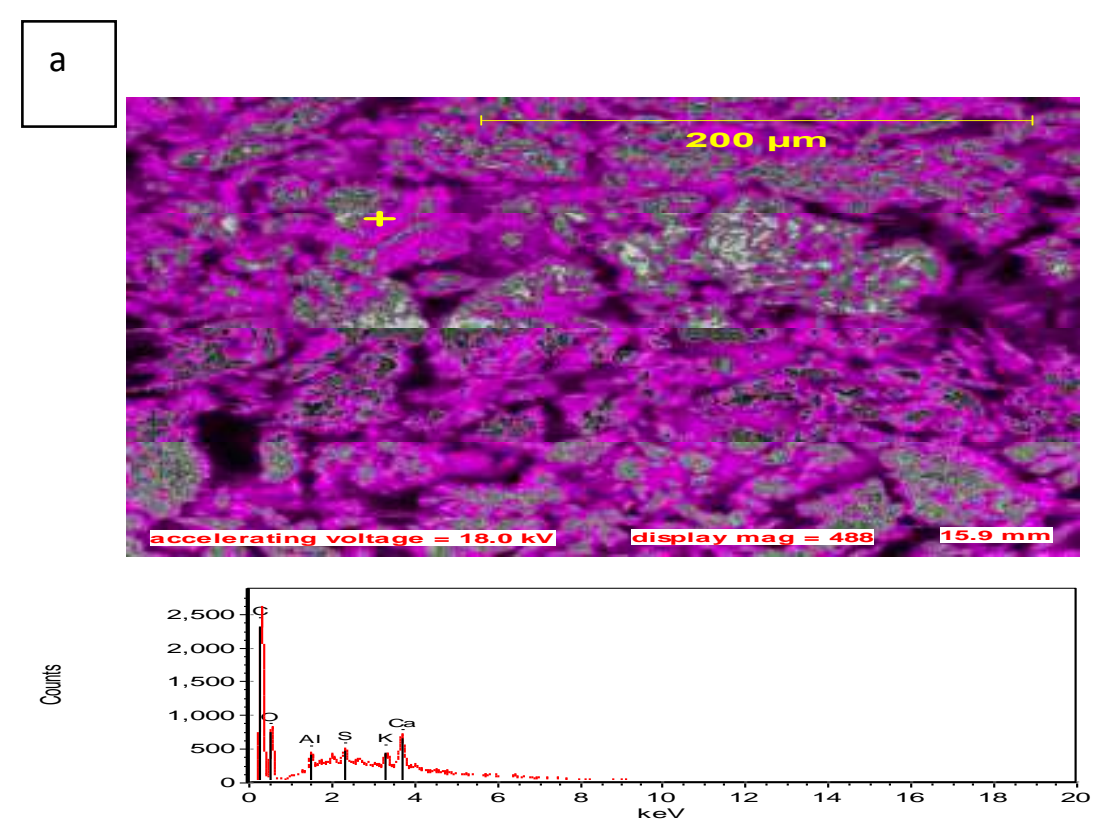

\section{b}
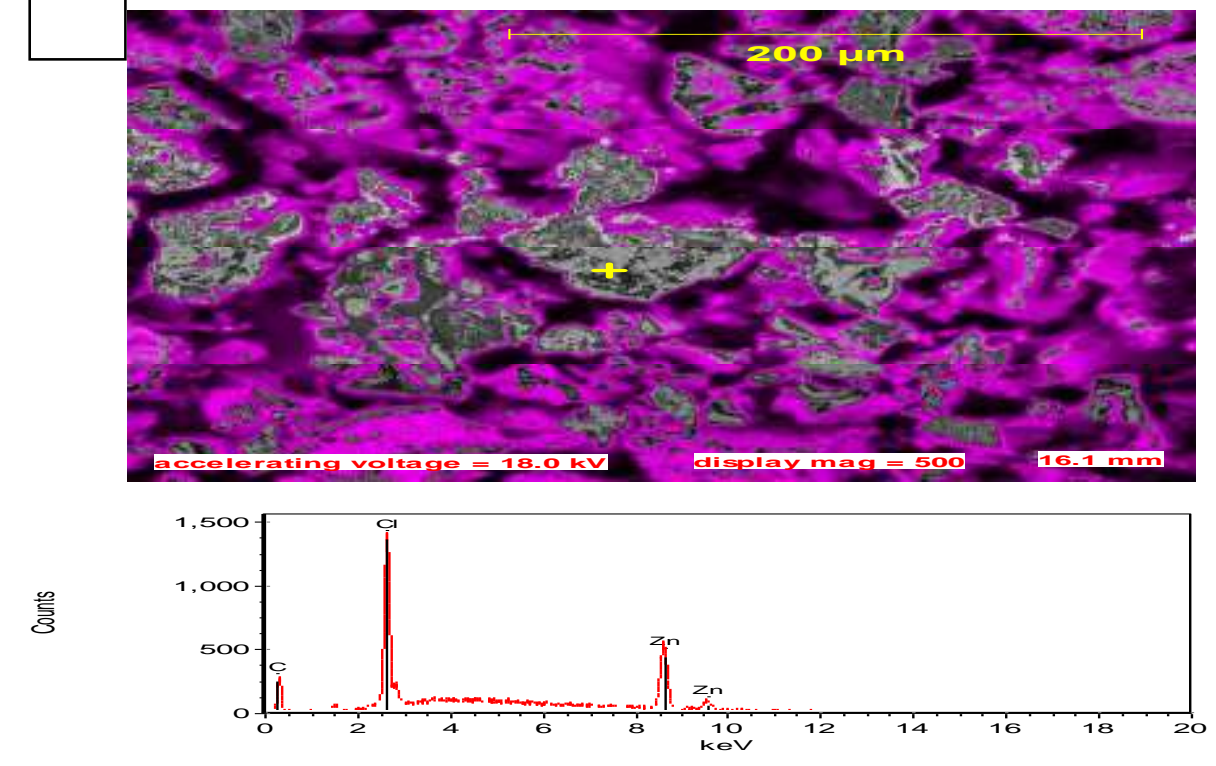

Figure 1: SEM of the biomass (a) and the ACZ (b) 


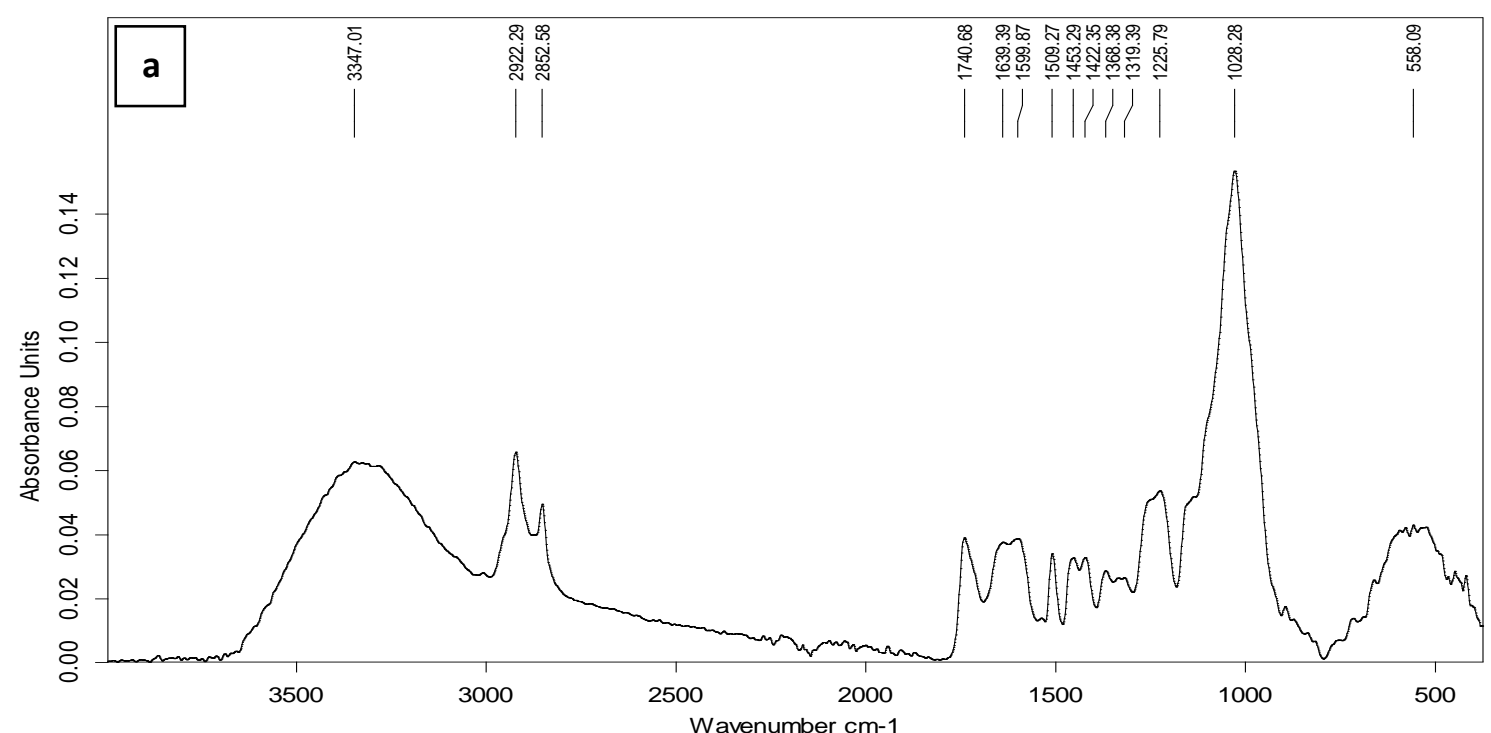

C:IDocuments and SettingsILCAIApplication DatalOPUS_65IMEASIMKI Biomasse.0 MKI Biomasse Instrument type and / or accessory

Seite 1 von 1

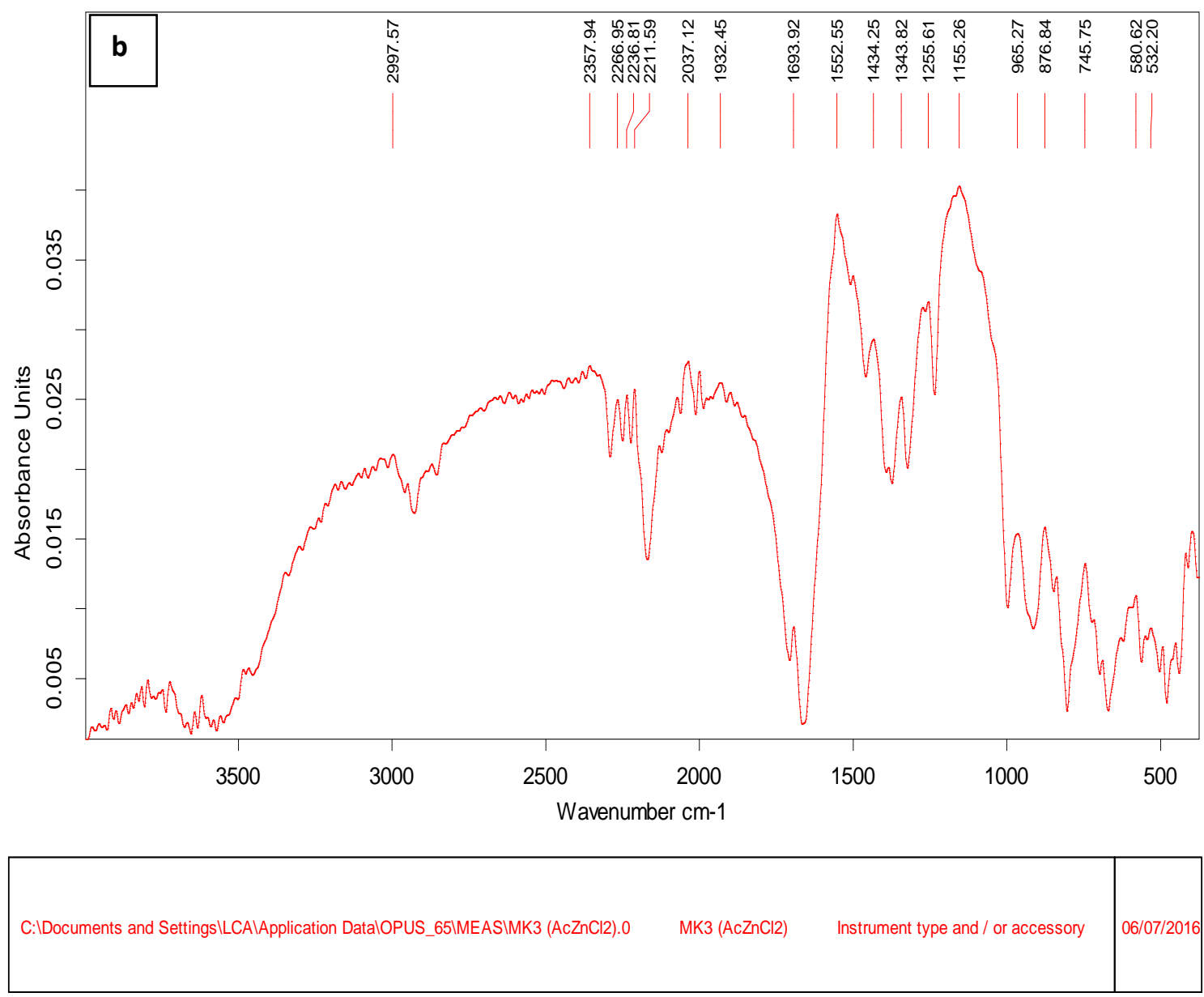

Seite 1 von 1 


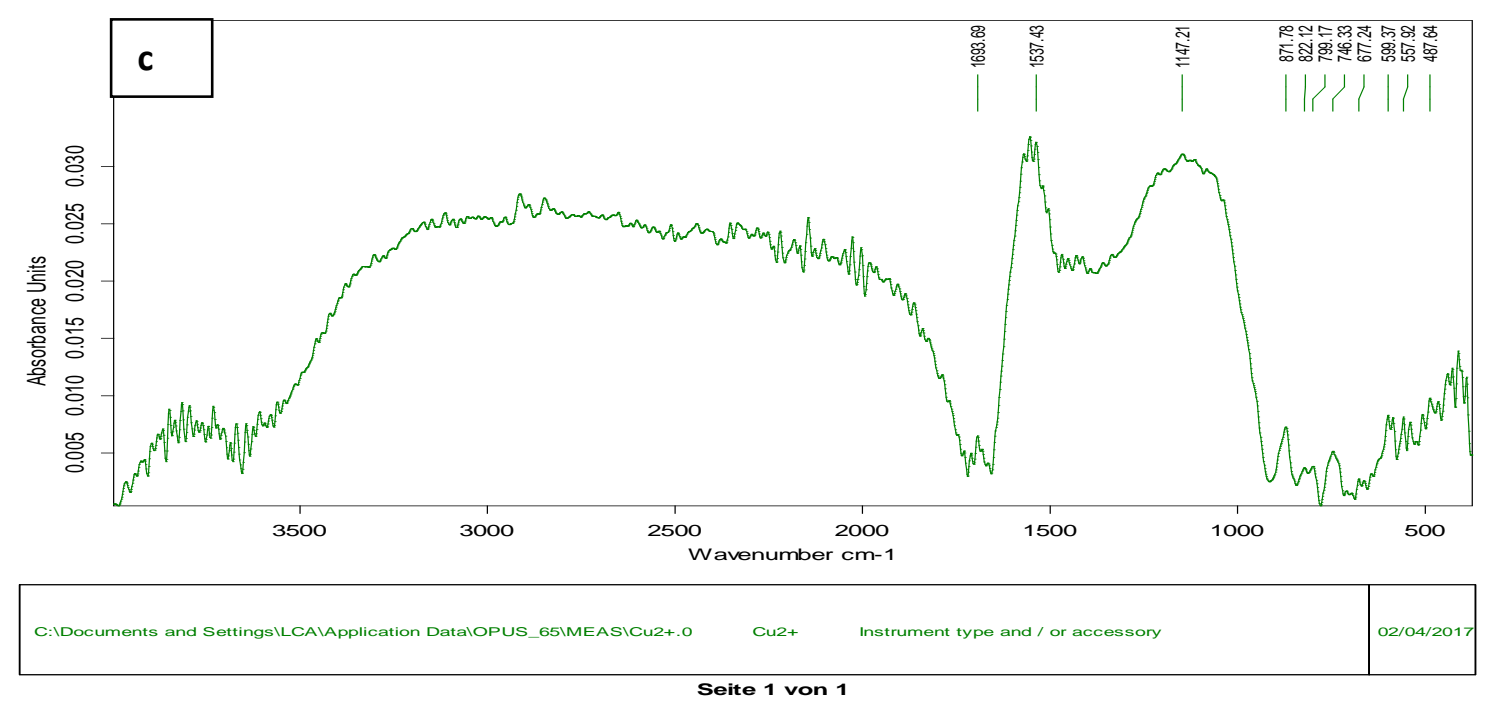

Figure 2: FTIR spectra of biomass (a), $\mathrm{ACZ}(\mathrm{b})$ and $\mathrm{ACZ}$ after adsorption (c) of $\mathrm{Cu}^{2+}$ ions

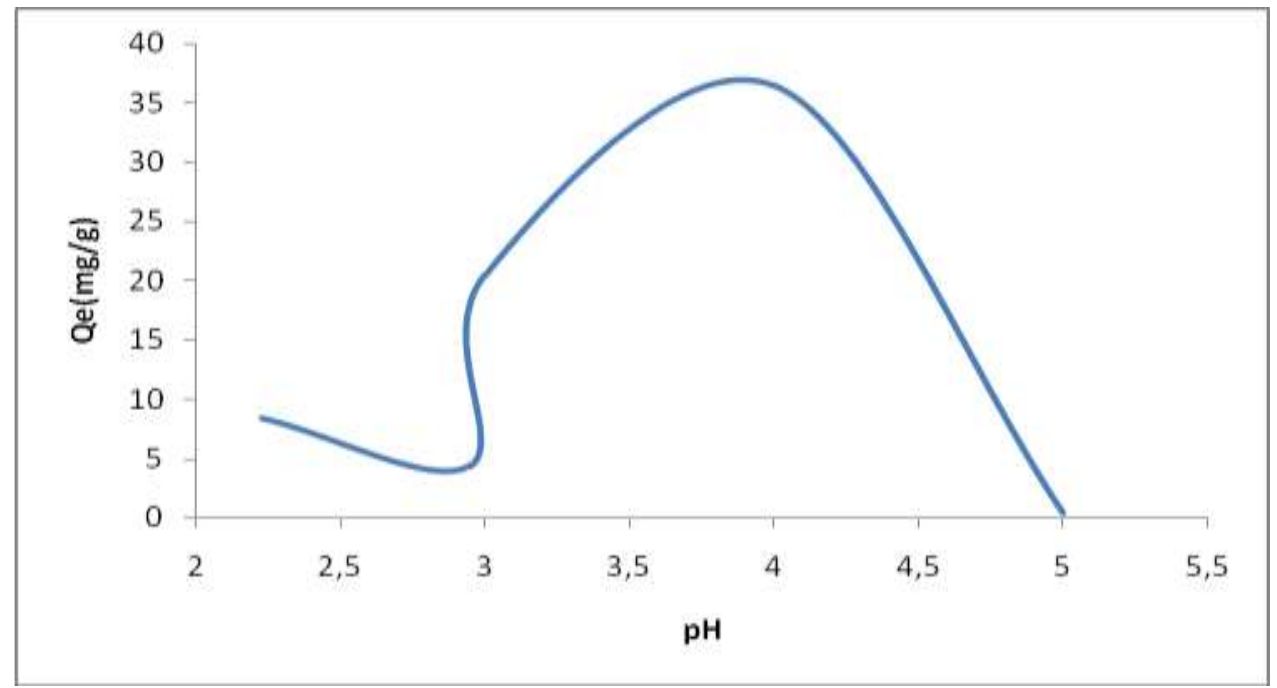

Figure 3: Quantity adsorbed as a function of $\mathrm{pH}$ 


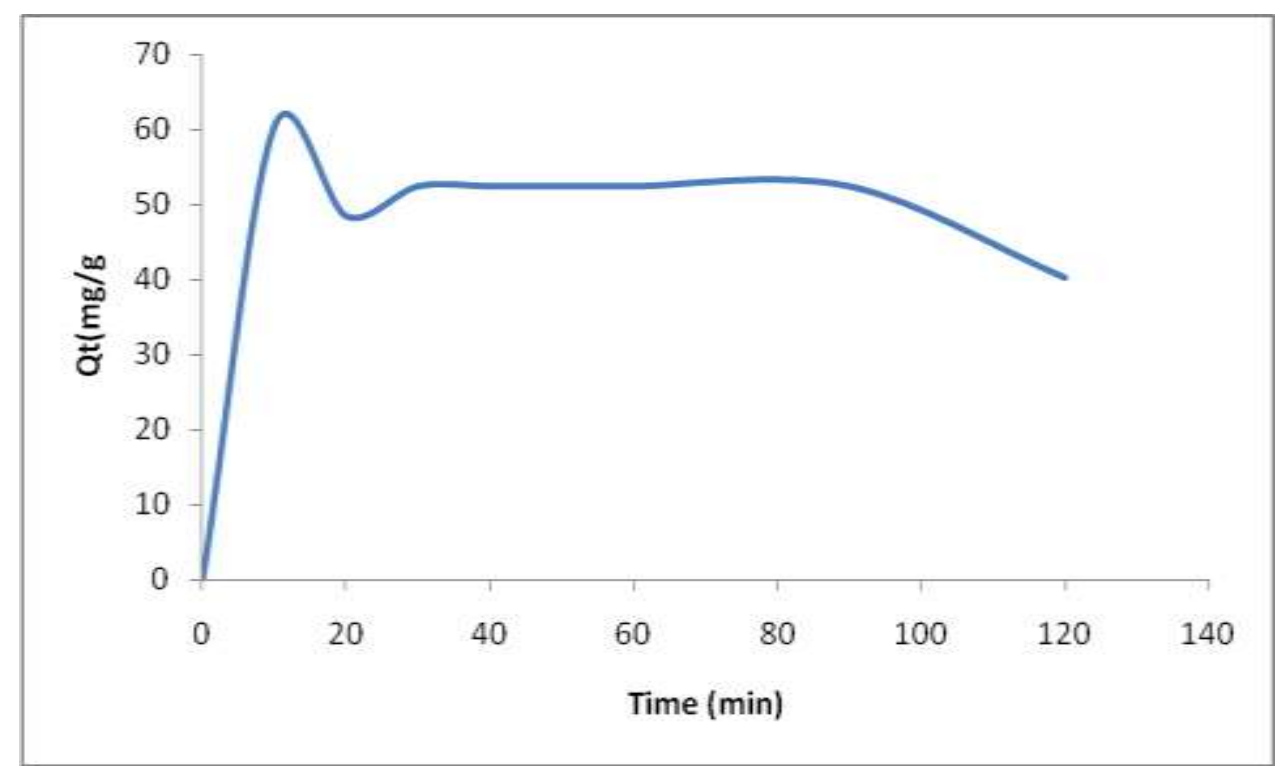

Figure4: Variation of contact time of the adsorption of $\mathrm{Cu}^{2+} \mathrm{ACZ}$

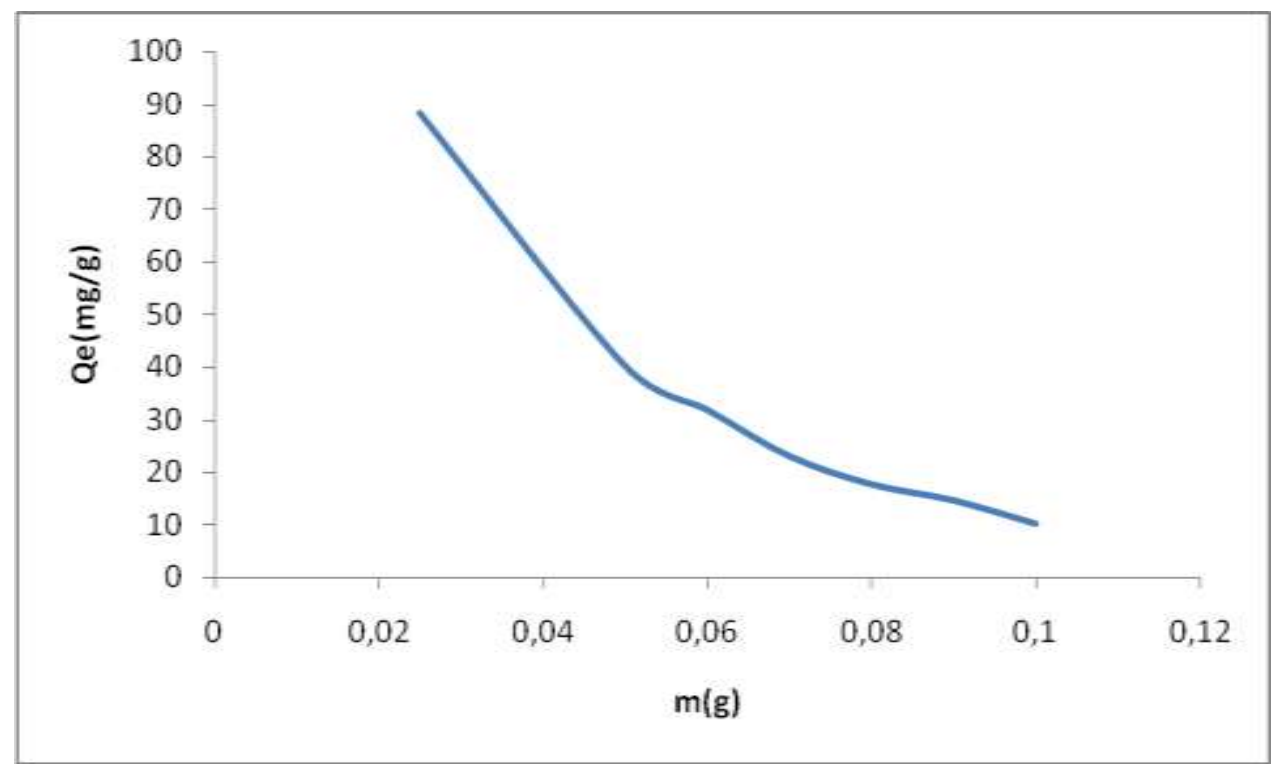

Figure 5: Effect of adsorbent dose 


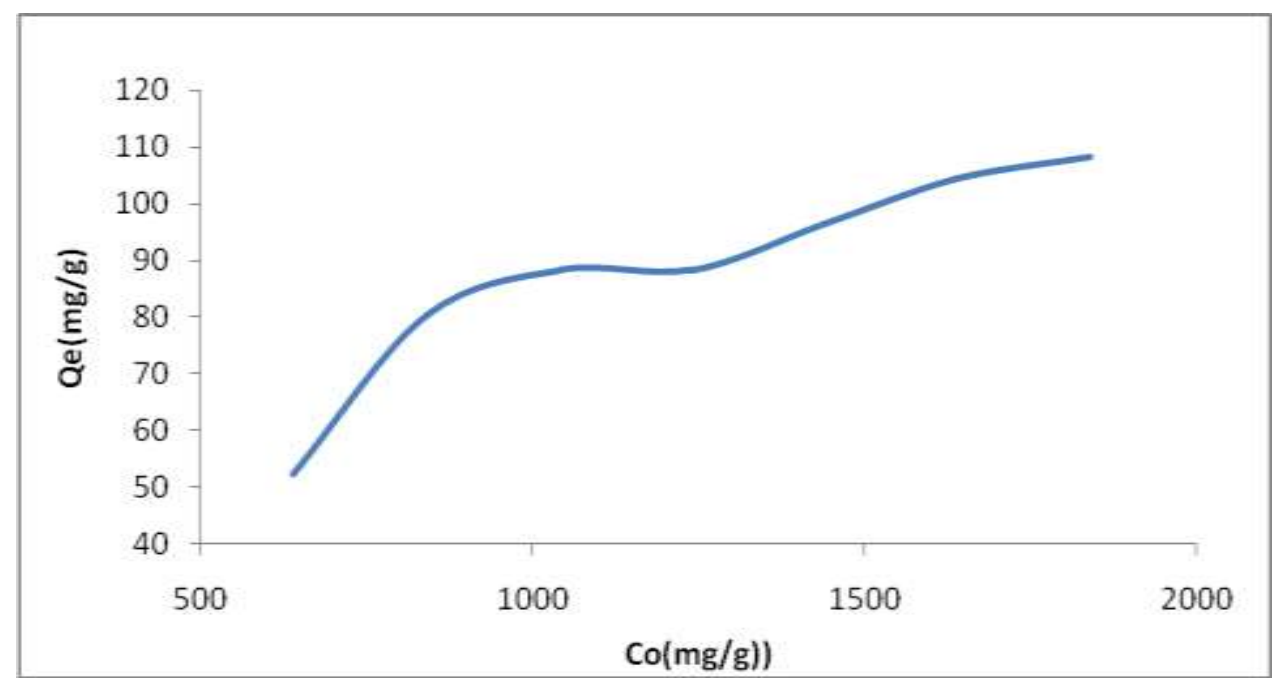

Figure6: Effect of initial concentration of $\mathrm{Cu}^{2+}$ ions

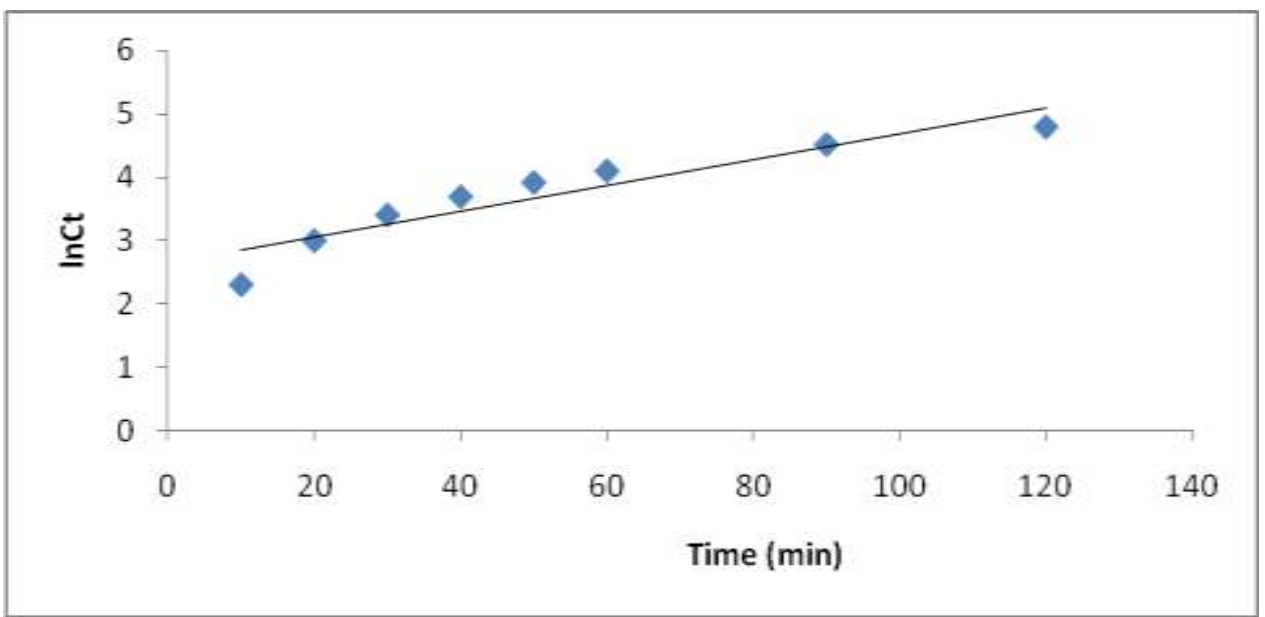

Figure 7:Pseudo-first order kinetics adsorption model of $\mathrm{Cu}^{2+}$ ions onto $\mathrm{ACZ}$ 


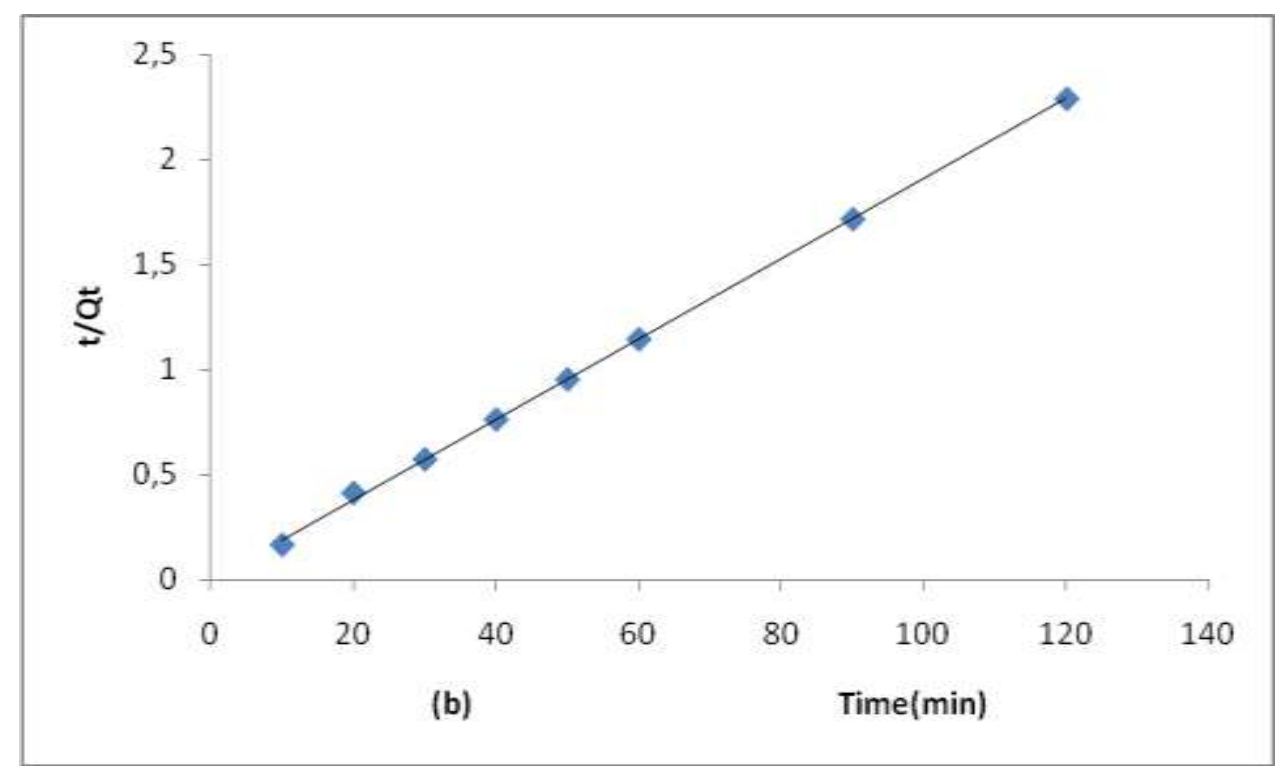

Figure 8: Pseudo-second order kinetics adsorption model of $\mathrm{Cu}^{2+}$ onto $\mathrm{ACZ}$
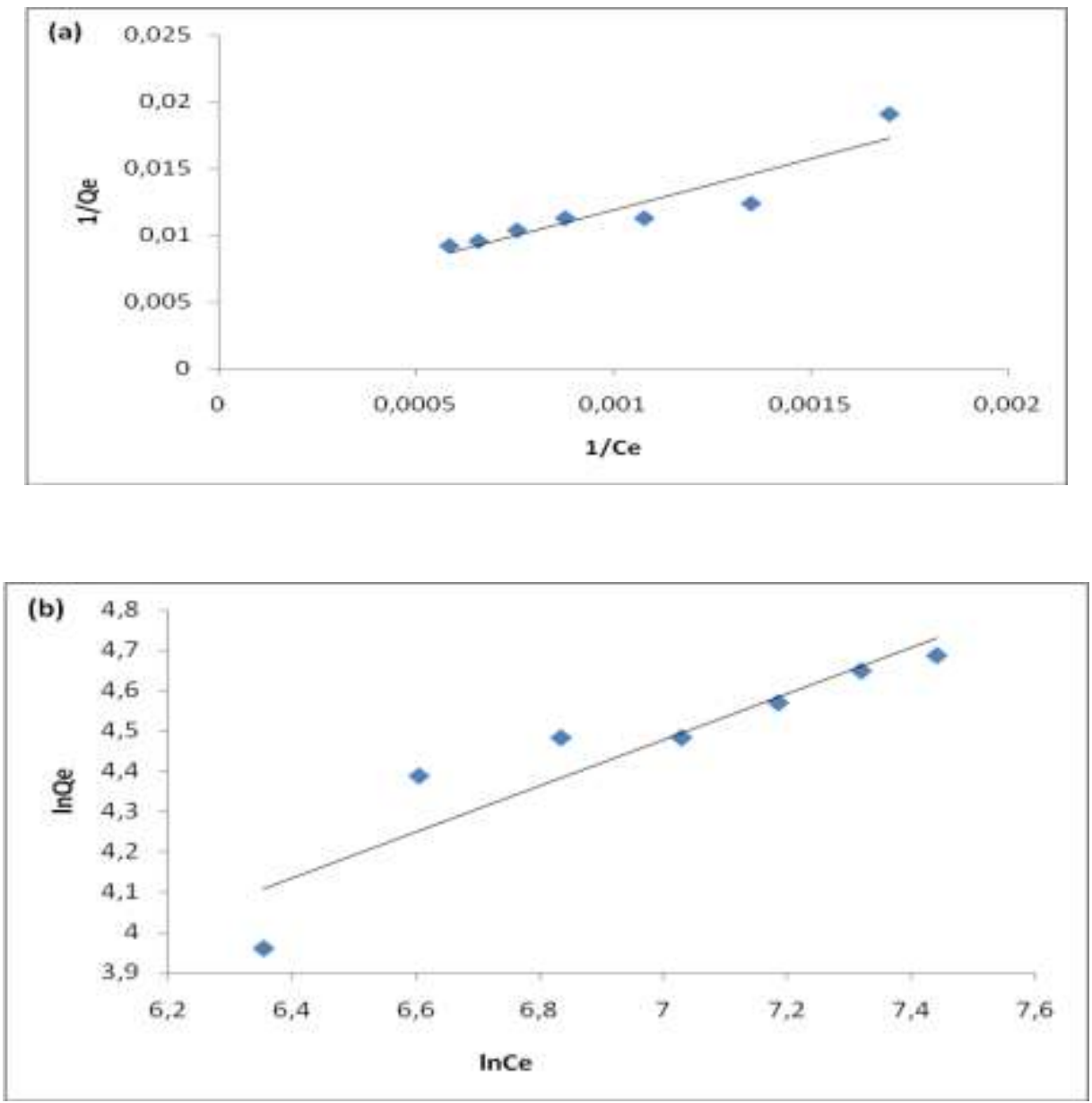


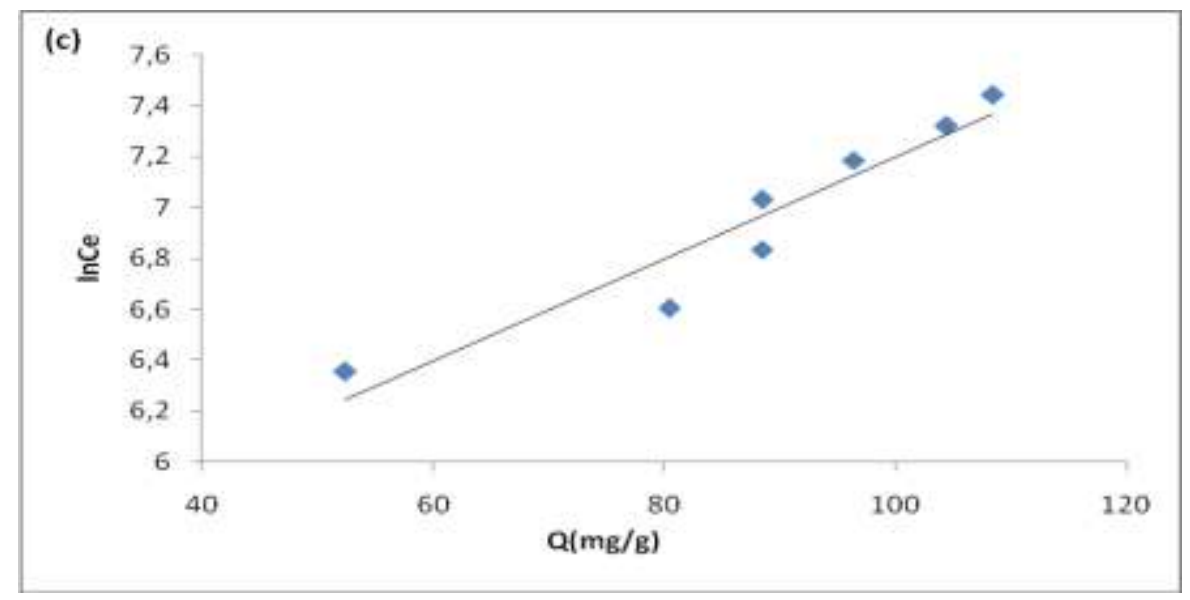

Figure 8:: Langmuir isotherm (a), Freundlich isotherm (b) and Tempkin isotherm (c) of $\mathrm{Cu}^{2+}$ onto $\mathrm{ACZ}$

Table 1: Kinetics constants for the adsorption of $\mathrm{Cu}^{2+}$ on $\mathrm{ACZ}$

\begin{tabular}{|c|c|c|c|c|c|}
\hline \multicolumn{2}{|c|}{ Pseudo-first-order } & \multicolumn{2}{c|}{ Pseudo- second order } \\
\hline $\mathrm{K}_{1}\left(\mathrm{~min}^{-1}\right)$ & $\mathrm{Q}_{\mathrm{e}}(\mathrm{mg} / \mathrm{g})$ & $\mathrm{R}^{2}$ & $\mathrm{~K}_{2}(\mathrm{~g} \cdot \mathrm{min}-1 . \mathrm{m}-1)$ & $\mathrm{Q}_{\mathrm{e}}(\mathrm{mg} / \mathrm{g})$ & $\mathrm{R}^{2}$ \\
\hline 0,020 & 13,970 & 0,934 & 52,63 & - & 0,999 \\
\hline
\end{tabular}

Table 2: Isotherm parameter for the adsorption of $\mathrm{Cu}^{2+}$ on $\mathrm{ACZ}$

\begin{tabular}{|l|l|l|l|l|l|l|l|}
\hline $\begin{array}{l}\text { Langmuir } \\
\text { isotherm constant }\end{array}$ & \multicolumn{2}{|l|}{$\begin{array}{l}\text { Freundlich } \\
\text { isotherm constant }\end{array}$} & \multicolumn{2}{l|}{$\begin{array}{l}\text { Tempkin } \\
\text { isotherm constant }\end{array}$} \\
\hline $\mathrm{Q}(\mathrm{mg} / \mathrm{g})$ & $\mathrm{K}_{\mathrm{Lx}} 10^{-4}$ & $\mathrm{R}^{2}$ & $\mathrm{~K}_{\mathrm{F}}$ & $1 / \mathrm{n}$ & $\mathrm{R}^{2}$ & $\mathrm{~B}$ & $\mathrm{R}^{2}$ \\
\hline 250.000 & 0,523 & 0,850 & 2,282 & 0,572 & 0,851 & 0,020 & 0,909 \\
\hline
\end{tabular}

